\title{
PENERAPAN ANGGARAN BELANJA TERHADAP KINERJA OPERASIONAL DI DINAS PERTANIAN DAN PANGAN KOTA MAGELANG
}

\author{
Oleh: \\ Yenny Yakub Sulistyawati \\ Siti Afidatul Khotijah \\ Program Studi Akuntansi Fakultas Ekonomi Universitas Tidar Magelang \\ email: yennyyakub8@gmail.com,khotijah_afi@untidar.ac.id
}

\begin{abstract}
ABSTRAK
Tujuan dari penelitian ini adalah untuk mengetahui sejauh mana penerapan anggaran belanja terhadap kinerja operasional di Dinas Pertanian dan Pangan Kota Magelang guna mendukung program kegiatan bagi masyarakat. Dalam penelitian ini yang digunakan dalam metode penelitian adalah analisis kualitatif dengan pendekatan deskriptif. Lokasi penelitian ini adalah Dinas Pertanian dan Pangan Kota Magelang. Teknik pengumpulan data dilakukan dengan observasi, dan wawancara. Setelah dilakukan penelitian, informasi dan hasil pengamatan dapat disimpulkan bahwa dalam mekanisme penerapan anggaran belanja di Dinas Pertanian dan Pangan Kota Magelang, setelah disahkan dan disetujui menjadi APBD maka RKA diubah menjadi DPA. Anggaran terhadap kinerja operasional di Dinas Pertanian dan Pangan Kota Magelang membuat berbagai macam program kegiatan yang dapat diikuti oleh masyarakat sehingga dapat dipergunakan dengan bijak dan membantu meningkatkan kesejahteraan. Selain itu, terdapat beberapa hambatan dalam pelaksanaan program kegiatan antara lain (1) hal yang tidak terduga dan berada diluar dari perencanaan serta; (2) adanya keterbatasan SDM di Dinas Pertanian dan Pangan Kota Magelang.
\end{abstract}

Kata Kunci: Penerapan Anggaran Belanja, Kinerja Operasional, Dinas Pertanian dan Pangan Kota Magelang

\begin{abstract}
The purpose of this research is to determine the extent to wich the implementation of the budget for operational performance in the Dinas Pertanian dan Pangan Kota Magelang to support program activities for the public. In this study, the research method used is qualitative analysis with a descriptive approach. The location of this research is Dinas Pertanian dan Pangan Kota Magelang. Data collection techniques are done with observation, and interviews. After the research, information and observation results can be concluded that in the mechanism of implementation of the budget in the Dinas Pertanian dan Pangan Kota Magelang, after ratified and approved into APBD then RKA converted to DPA. The budget to the operational performance in the Dinas Pertanian dan Pangan Kota Magelang makes a variety of activities that can be followed by the community so that it can be used wisely and help improve the welfare. In addition, there are several barriers to the implementation of activities programs, among others (1) that are unpredictable and out of planning as well; (2) There are limited human resources in the Dinas Pertanian dan Pangan Kota Magelang.
\end{abstract}

Keywords: Implementation of the Budget, Operational Performance, Dinas Pertanian dan Pangan Kota Magelang 


\section{PENDAHULUAN}

Anggaran sangat dibutuhkan bagi pemerintah guna melaksanakan roda pemerintahnya. Anggaran yaitu pernyataan tentang penilaian kinerja yang akan diraih oleh suatu lembaga dalam kurun waktu yang ditentukan dan diakui dalam ukuran finansial (Noratika dkk, 2016). Dalam organisasi sektor publik, anggaran adalah alat akuntabilitas untuk melaksanakan program yang didanai oleh dana publik dan mengelola dana publik. Data yang telah didapatkan dari masa lampau untuk tumpuan anggaran, anggaran sektor publik juga dapat diartikan sebagai rencana keuangan untuk taksiran penerimaan dan pengeluaran yang diharapkan terjadi di masa yang akan datang.

Proses yang cukup rumit adalah penganggaran dalam organisasi sektor publik. Penganggaran sektor publik dengan penganggaran pada sektor swasta mempunyai karakteristik yang berbeda. Rahasia perusahaan yang tidak diungkapkan ke publik adalah bagian pada anggaran sektor swasta, tapi di sisi lain yang seharusnya diumumkan kepada publik untuk dievaluasi, dipertimbangkan dan dimusyawarahkan untuk memperoleh saran adalah anggaran sektor publik (Sri Rahayu, 2007).

Menurut buku Mardiasmo dengan judul Akuntansi Sektor Publik (2002: 63-69) menyatakan anggaran sektor publik mempunyai sebagian fungsi utama, yaitu: a) anggaran sebagai alat perencanaan (Planning Tool); b) anggaran sebagai alat pengendalian; c) anggaran sebagai alat kebijakan fiskal; d) anggaran sebagai alat politik; e) anggaran sebagai alat komunikasi dan koordinasi; f) anggaran sebagai alat penilaian kinerja; g) anggaran sebagai alat motivasi, dan; h) anggaran sebagai alat untuk menciptakan ruang publik. Fungsifungsi tersebut dapat mendukung pelaksanaan anggaran.

Dinas Pertanian dan Pangan Kota Magelang memiliki penerapan anggaran belanja yang dimulai pada tahap perencanaan, pelaksanaan dan pelaporan. Penganggaran dalam Dinas Pertanian dan Pangan Kota Magelang ini sebagai pengelolaan rencana strategis untuk melakukan tujuan yang hendak dicapai, yakni memberikan pelayanan publik yang ramah dan berguna bagi masyarakat sekitar Kota Magelang. Anggaran dapat memenuhi tujuan yang ingin dicapai, sehingga dalam proses penyusunan anggaran, antara atasan dan bawahan, pimpinan dan karyawan harus memiliki kerjasama yang baik.

Dinas Pertanian dan Pangan Kota Magelang dipimpin oleh Kepala Dinas yang bertanggungjawab kepada Walikota melalui Sekretaris Daerah. Dinas Pertanian dan Pangan bertanggungjawab mendukung 
Walikota dalam menjalankan urusan pemerintahan di bidang pertanian, pangan, perikanan dan peternakan yang telah menjadi tanggungjawab pemerintah daerah dan ditugaskan oleh Pemerintah Daerah.

Kota Magelang terletak di dalam wilayah Provinsi Jawa Tengah. Kota Magelang mempunyai lokasi strategis. Kondisi pertanian di Kabupaten Magelang mempunyai potensi luar biasa. Pegunungan dengan kandungan tanah vulkanik adalah sumber utama kesuburan yang tak pernah habis. Tantangan dunia pertanian modern semakin realistis. Inovasi dan petugas diharapkan terus mengembangkan diri agar tidak ketinggalan. Dinas pertanian didorong terus untuk bergerak, tumbuh dan berkembang.

\section{Pada Peraturan Pemerintah nomor 8} Tahun 2006, yaitu Pelaporan Keuangan dan Kinerja instansi Pemerintah menunjukkan kinerja merupakan kesimpulan dari program dan kegiatan yang akan atau sudah tercapai terkait atas penggunaaan anggaran dengan kualitas dan kuantitas terukur. Input (masukan) dan output (keluaran) mempunyai hubungan untuk menentukan kinerja. Kinerja dapat dievaluasi melalui pengukuran penilaian yang berdasarkan pada indikator (Sancoko, 2008) masukan (input) adalah ukuran kinerja untuk menjalankan program dan atau kegiatan yang didasarkan pada tingkat atau besaran dari sumber daya manusia, sumber dana, material dan lain sebagainya. Selanjutnya keluaran (output), adalah ukuran kinerja untuk menghasilkan program atau kegiatan yang sesuai dengan masukan yang dipakai berdasarkan produk (barang atau jasa) yang dihasilkan. Hasil (outcome), adalah ukuran kinerja untuk keluaran program atau kegiatan yang telah dijalankan berdasarkan tingkat keberhasilan yang telah dicapai. Manfaat (benefit), adalah ukuran kinerja didasarkan pada tingkat kemaanfaatan yang dapat dirasakan masyarakat dan pemerintah daerah dari hasil. Dampak (impact), adalah ukuran kinerja yang didasarkan pada pengaruh dengan kondisi makro yang akan dicapai dari manfaat.

Penelitian yang dilakukan oleh Mirna (2013) mengemukakan bahwa dalam implementasi penyusunan anggaran fenomena penggunaan pendekatan traditional budget atau line item, terutama dalam perencanaan anggaran masih sering ditemui. Adapun, dalam pembentukan anggaran berbasis kinerja terdapat beberapa kendala yaitu (1) terbatasnya wawasan, pemahaman dan serta dorongan dari para karyawan untuk menggunakan anggaran kinerja dengan maksimal; (2) kurangnya sistem pengukuran kinerja atas outcome yang dihasilkan. Kemudian penelitian yang dilakukan oleh Venni (2013) menyatakan bahwa implementasi anggaran kinerja berdampak positif terhadap kinerja program peningkatan disiplin aparatur instansi 
pemerintah daerah. Penelitian yang dilakukan oleh Espinoza (2014) menyatakan bahwa Kota Medan masih sangat rendah dan mengarah pada penurunan usai pelaksanaan anggaran berbasis kinerja rasio kemandirian keuangan. Begitu pula dengan hasil rata-rata $21,43 \%$ per tahunnya yang dikategorikan masih sangat rendah yaitu derajat desentralisasi fiscal setelah anggaran berbasis kinerja. Dalam pelaksanaan anggaran belanja menunjukkan keberhasilan dan pertumbuhan belanja membuktikan pertumbuhan yang positif. Setelah anggaran berbasis kinerja dapat menunjukkan hasil yang cukup bagus maka kinerja keuangan pemerintah Kota Medan tetap seimbang. Pasalnya, PAD mengalami peningkatan, meski selanjutnya mendapat bantuan dari pemerintah pusat. Selanjutnya penelitian yang dilakukan oleh Hendra Cipta (2011) hasil penelitian menyatakan bahwa hampir keseluruhan indikator kinerja yang dipakai dalam dokumen anggaran tersebut tidak mencukupi kriteria indikator kinerja yang baik. Indikator kinerja tidak dapat langsung berkaitan dengan anggaran yang telah diputuskan untuk kegiatan yang saling berhubung karena keadaan tersebut berdampak pada pengguna indikator kinerja dalam penyusunan anggaran.

Beberapa Penelitian Terdahulu telah disebutkan diatas beserta hasil penelitiannya. Perbedaan yang terdapat dengan penelitian sekarang terletak pada subjek dan variabel penelitian yang digunakan. Sedangkan tujuan peneliti dari penelitian sekarang adalah untuk mengetahui sejauh mana penerapan anggaran belanja terhadap kinerja operasional di Dinas Pertanian dan Pangan Kota Magelang guna mendukung program kegiatan bagi masyarakat.

\section{KAJIAN PUSTAKA}

\section{Anggaran}

Penganggaran (budgeting) adalah kegiatan mengalokasikan sumber daya keuangan yang menyediakan dana untuk pengeluaran organisasi, dan pengeluaran organisasi seringkali tidak terbatas (Haryanto, Sahmuddin, Arifuddin: 2007). Sedangkan menurut Nafarin (2013:11), mendifinisikan bahwa "Anggaran (budget) adalah perencanaan yang dicatat untuk kegiatan yang terkait dengan organisasi yang ditunjukkan dalam mata uang, dan juga dapat ditunjukkan dalam unit barang/jasa." Dari beberapa penjelasan tersebut, dapat disimpulkan bahwa anggaran secara umum ialah hal yang sangat penting dalam perencanaan yang disusun secara sistematis guna mencapai sasaran organisasi. Anggaran juga menjadi alat untuk mengendalikan kegiatan organisasi yang akan dilaksanakan.

Anggaran juga memiliki banyak fungsi dan fungsi-fungsi tersebut saling terkait. Menurut Supriyono (1999:343) 
fungsi anggaran meliputi; 1) fungsi perencanaan, dapat menentukan pilihan tertentu untuk dilakukan di masa mendatang dengan menimbang sasaran perusahaan, adanya sumber daya ekonomi dan hambatan yang akan dijumpai di masa mendatang;2) fungsi koordinasi yang dikaitkan dengan perilaku berbagai bagian atau departemen di dalam perusahaan supaya bisa bekerja dengan harmonis untuk mencapai sasaran; 3) fungsi komunikasi, selama penyusunan anggaran, berbagai departemen dan tingkatan organisasi saling berhubungan dan berpartisipasi; 4) fungsi motivasi, anggaran juga dapat digunakan sebagai cara agar mendorong para pelaksana dalam menjalankan tugas atau mencapai sasaran; 5) fungsi pengendalian dan evaluasi, karena anggaran yang sudah disepakati adalah tanggung jawab pelaksana yang ikut berpartisipasi atas penyusunan anggaran tersebut, dan; 6) fungsi pendidik, untuk membimbing para manajer terkait bagaimana melakukan pekerjaan secara terinci di pusat pertanggungjawaban yang dipimpin.

\section{Kinerja Operasional}

$$
\text { Menurut Daft (2010, p216) }
$$
operational performance memiliki arti yaitu merupakan bagian manajemen yang mengutamakan dalam produksi barang dan jasa, serta memakai alat dan teknik tertentu untuk menyelesaikan urusan produksi.
Pengertian kinerja operasional (operational performance) menurut Handoko (2010, p8), adalah kegiatan manajerial dilaksanakan dan dibawakan dalam penyusunan, pemilihan, pengoperasian inovasi, dan pengendalian sistem-sistem produksi.

Demi mencapai kinerja operasi tujuan organisasi yaitu dengan melaksanakan fungsi-fungsi. Fungsi perencanaan (planning) yaitu ketetapan yang terkait dengan ide untuk struktur perwujudan suatu operasi produktif. Fungsi pengorganisasian (organizing) yaitu ketetapan rancangan tingkat keluaran secara berkepanjangan atau dasar perkiraan permintaan dan keputusan perencanaan kerja dan pengalokasian pegawai jangka pendek. Dalam fungsi pengarahan (actuating) yaitu ketetapan yang dibuat atas sistem produksi yang didasarkan pada permintaan yang diubah, tujuan organisasional dan manajemen. Fungsi yang terakhir adalah fungsi pengawasan (controlling) yaitu operasi produksi barang atau penyediaan jasa dengan prosedur terkait pengambilan tindakan korektif.

\section{METODE PENELITIAN}

Metode penelitian ini menggunakan deskriptif kualitatif. Menurut Djam'an Satori (2011:23) peneliti yang menggunakan penelitian kualitatif ingin mengekspor kejadian-kejadian yang tidak dapat dikuantifikasikan dengan bersifat 
deskriptif. Penelitian deskriptif kualitatif merupakan penelitian yang menjelaskan suatu objek penelitian yang didasarkan dengan fenomena-fenomena yang muncul atau apa adanya, Nawawi dan Martini (1996:73). Bahwa penelitian deskriptif kualitatif adalah kumpulan aktivitas untuk mendapatkan data yang bersifat sebagaimana adanya. Metode ini dipilih karena bertujuan untuk memahami penerapan anggaran belanja terhadap kinerja operasional di Dinas Pertanian dan Pangan Kota Magelang.

Wawancara dan dokumentasi adalah teknik pengumpulan data yang digunakan pada penelitian ini. Melakukan wawancara dengan memberikan pertanyaan serta menjawab antara penanya atau pewawancara dengan penjawab atau responden. Peneliti sesekali menanggapi jawaban responden, dengan meminta penjelasan. Pihak yang diwawancara diantaranya adalah Kepala Bagian Program dan Keuangan dan staff/karyawan Dinas Pertanian dan Pangan. Dokumen yang digunakan untuk kebutuhan membantu melengkapi pelaksanaan penelitian, yaitu Laporan Kinerja Instansi Pemerintah (LKJiP) Dinas Pertanian dan Pangan Kota Magelang.

\section{HASIL DAN PEMBAHASAN}

\section{Penerapan Anggaran Belanja Dinas} Pertanian dan Pangan Kota Magelang

Anggaran belanja pada kinerja operasional yang akan dijalankan oleh Dinas Pertanian dan Pangan Kota Magelang harus dibuat perencanaan dalam menyusun anggaran belanja agar dapat memaksimalkan proses kegiatan pelaksanaan program kerja. Dinas Pertanian dan Pangan Kota Magelang memiliki perencanaan jangka pendek, jangka menengah dan jangka panjang. Perencanaan jangka pendek hanya mencakup untuk 1 tahun.

Kegiatan perencanaan penganggaran Dinas Pertanian dan Pangan Kota Magelang diawali ditahun sebelumnya dengan menyusun Rencana Kerja, karena itu sebagai pedoman untuk tahun berikutnya. Melalui proses pembahasan intern dilakukan untuk mematangkan masingmasing unit seksi atau bidang dan termasuk juga unit kerja UPT Puskeswan dan UPT $\mathrm{RPH}$, selanjutnya dapat merencanakan anggaran dan merencanakan apa saja yang akan dilakukan lalu dituangkan dalam bentuk anggaran beserta berapa besaran nominalnya. Setelah itu akan digabung menjadi milik Dinas Pertanian dan Pangan Kota Magelang dan dibawa ke BAPERDA untuk dibahas dalam tim Renja, maka setelah disetujui selanjutnya akan dibahas 
bersama untuk mengetahui sejauh mana kesesuaian dengan perencanaan jangka menengah maupun jangka panjang dan proses ini dilakukan secara makro.

Proses mikro di Dinas Pertanian dan Pangan Kota Magelang dilakukan secara tahunan untuk membuat kegiatan-kegiatan apa saja yang akan dilakukan dan seberapa banyak jumlah anggaran yang dibutuhkannya. Setelah disetujui dengan daerah kota, tim Renja membahas lagi sejauh mana kesesuaian dengan perencanaan jangka menengah dan jangka panjang dengan tim legislatif. Selanjutnya akan diterbitkan Perwal terkait Rencana Kerja, namun kebijakan pembahasannya masuk didalam KUA PPAS (Kebijakan Umum Anggaran Prioritas Plafon Anggaran Sementara). Adapun pembahasan hasil dari Renja, yaitu adanya PerWal (Peraturan Walikota) tentang Rencana Kerja Daerah dan munculnya kebijakan dengan legislator yaitu KUA PPAS.

\section{Mekanisme Pelaksanaan Anggaran Belanja}

Perencanaan kerja yang telah disetujui dan disahkan, saat menjelang akhir tahun APBD (Anggaran Pendapatan dan Belanja Daerah) sudah harus ditetapkan dan telah mendasar kepada Renja. Dalam pembahasan APBD sudah harus terinci karena untuk menjadi pedoman pelaksanaan atau realisasi pada tahun berikutnya. Jika sudah memasuki tahun berikutnya pada awal tahun sudah harus ada pengeluaran dan APBD sudah bisa digunakan. Setelah disahkan dan disetujui menjadi APBD maka RKA (Rencana Kerja Daerah) diubah menjadi DPA (Dokumen Pelaksanaan Anggaran) yang telah menjadi pegangan karena sudah ada berbagai rincian anggaran dan tidak boleh keluar dari yang telah disediakan.

Peraturan yang telah ditetapkan, yang berwenang dalam hal pelaksanaan anggaran di Dinas Pertanian dan Pangan Kota Magelang adalah PA (Pengguna Anggaran), yaitu Kepala Dinas Pertanian dan Pangan Kota Magelang. Kepala Dinas berwenang karena diberikan perintah langsung dari Wali Kota Magelang. Namun dalam pelaksanaan anggaran tersebut PA akan medelegasikan kepada bawahannya, yaitu melalui bidang-bidang, melalui sekretariat. Kepala Bidang juga diturunkan ke tingkat pelaksanaan kegiatan yang disebut PPTK (Pejabat Pelaksana Teknis Kegiatan) dan juga harus bertanggungjawab dalam setiap kegiatan. Berikut tabel yang menunjukkan pada Pejabat Pelaksana Teknis Kegiatan. 
Tabel 1. Penunjukan Pejabat Pelaksanaan Teknis Kegiatan (PPTK)

Belanja Langsung Pada Dinas Pertanian Dan Pangan Kota Magelang

Tahun Anggaran 2020

\begin{tabular}{|c|c|c|c|}
\hline No. & $\begin{array}{l}\text { Pejabat Pelaksanaan } \\
\text { Teknis Kegiatan }\end{array}$ & Program/Kegiatan & $\begin{array}{l}\text { Jumlah } \\
\text { Anggaran }\end{array}$ \\
\hline \multirow[t]{4}{*}{1.} & \multirow{4}{*}{$\begin{array}{l}\text { Kepala Sub Bagian } \\
\text { Umum dan } \\
\text { Kepegawaian }\end{array}$} & $\begin{array}{l}\text { Program Pelayanan Administrasi } \\
\text { Perkantoran }\end{array}$ & $674.636,000,00$ \\
\hline & & $\begin{array}{l}\text { Program Peningkatan Sarana dan } \\
\text { Prasarana Aparatur }\end{array}$ & $292.350 .000,00$ \\
\hline & & $\begin{array}{l}\text { Program Peningkatan Kapasitas } \\
\text { Sumber Daya Aparatur OPD }\end{array}$ & $34.738 .000,00$ \\
\hline & & Jumlah & $1.001 .724 .000,00$ \\
\hline \multirow[t]{4}{*}{2.} & \multirow[t]{4}{*}{$\begin{array}{l}\text { Kepala Sub Bagian } \\
\text { Program dan Keuangan }\end{array}$} & $\begin{array}{l}\text { Program Pelayanan Administrasi } \\
\text { Perkantoran }\end{array}$ & $125.000 .000,00$ \\
\hline & & $\begin{array}{l}\text { Program Peningkatan Penembangan } \\
\text { Sistem Pelaporan Capaian Kinerja }\end{array}$ & $55.288 .000,00$ \\
\hline & & $\begin{array}{l}\text { Program Peningkatan Pemasaran } \\
\text { Hasil Produksi } \\
\text { Pertanian/Perkebunan }\end{array}$ & $109.192 .000,00$ \\
\hline & & Jumlah & $289.480 .000,00$ \\
\hline \multirow[t]{2}{*}{3.} & \multirow{2}{*}{$\begin{array}{l}\text { Kepala Seksi } \\
\text { Ketersediaan dan } \\
\text { Distribusi Pangan pada } \\
\text { Bidang Ketahanan } \\
\text { Pangan }\end{array}$} & $\begin{array}{l}\text { Program Peningkatan Ketahanan } \\
\text { Pangan Pertanian/Perkebunan }\end{array}$ & $187.033 .000,00$ \\
\hline & & Jumlah & 187.033.000,00 \\
\hline \multirow[t]{2}{*}{4.} & \multirow{2}{*}{$\begin{array}{l}\text { Kepala Seksi Konsumsi } \\
\text { dan Keamaan Pangan } \\
\text { pada Bidang Ketahanan } \\
\text { Pangan }\end{array}$} & $\begin{array}{l}\text { Program Peningkatan Ketahanan } \\
\text { Pangan Pertanian/Perkebunan }\end{array}$ & $255.066 .000,00$ \\
\hline & & Jumlah & $255.066 .000,00$ \\
\hline \multirow[t]{4}{*}{5.} & \multirow{4}{*}{$\begin{array}{l}\text { Kepala Seksi Prasarana } \\
\text { dan Sarana Pertanian } \\
\text { pada Bidang Pertanian }\end{array}$} & $\begin{array}{l}\text { Program Peningkatan Kesejahteraan } \\
\text { Petani }\end{array}$ & $522.457 .000,00$ \\
\hline & & $\begin{array}{l}\text { Program Peningkatan Pemasaran } \\
\text { Hasil Produksi } \\
\text { Pertanian/Perkebunan }\end{array}$ & $379.110 .000,00$ \\
\hline & & $\begin{array}{l}\text { Program Peningkatan Produksi } \\
\text { Pertanian/Perkebunan }\end{array}$ & $26.003 .000,00$ \\
\hline & & Jumlah & 927.570.000,00 \\
\hline \multirow[t]{4}{*}{6.} & \multirow{4}{*}{$\begin{array}{l}\text { Kepala Seksi Tanaman } \\
\text { Pangan dan Hortikultura } \\
\text { pada Bidang Pertanian }\end{array}$} & $\begin{array}{l}\text { Program Peningkatan Penerapan } \\
\text { Teknologi Pertanian/Perkebunan }\end{array}$ & $154.648 .000,00$ \\
\hline & & $\begin{array}{l}\text { Program Peningkatan Produksi } \\
\text { Pertanian/Perkebunan }\end{array}$ & $190.527 .000,00$ \\
\hline & & $\begin{array}{l}\text { Program Pemberdayaan Penyuluh } \\
\text { Pertanian/Perkebunan Lapangan }\end{array}$ & $79.074 .000,00$ \\
\hline & & Jumlah & 424.249.000,00 \\
\hline
\end{tabular}




\begin{tabular}{|c|c|c|c|}
\hline \multirow[t]{3}{*}{7.} & \multirow{3}{*}{$\begin{array}{l}\text { Kepala Seksi Perikanan } \\
\text { pada Bidang Peternakan } \\
\text { dan Perikanan }\end{array}$} & $\begin{array}{l}\text { Program Pengembangan Budidaya } \\
\text { Perikanan }\end{array}$ & $559.910 .000,00$ \\
\hline & & $\begin{array}{l}\text { Program Optimalisasai Pengelolaan } \\
\text { dan Pemasaran Produksi Perikanan }\end{array}$ & 296.789.000,00 \\
\hline & & $\begin{array}{l}\text { Jumlah } \\
\end{array}$ & $856.699 .000,00$ \\
\hline \multirow[t]{5}{*}{8.} & \multirow{5}{*}{$\begin{array}{l}\text { Kepala Seksi Peternakan } \\
\text { pada Bidang Peternakan } \\
\text { dan Perikanan }\end{array}$} & $\begin{array}{l}\text { Program Pencegahan dan } \\
\text { Penanggulangan Penyakit Ternak }\end{array}$ & $99.688 .000,00$ \\
\hline & & $\begin{array}{l}\text { Program Peningkatan Pemasaran } \\
\text { Hasil Produksi Peternakan }\end{array}$ & $269.128 .000,00$ \\
\hline & & $\begin{array}{l}\text { Program Peningkatan Penerapan } \\
\text { Teknologi Peternakan }\end{array}$ & $77.566 .000,00$ \\
\hline & & $\begin{array}{l}\text { Program Pelayanan Kesehatan } \\
\text { Masyarakat Veteriner }\end{array}$ & $56.410 .000,00$ \\
\hline & & Jumlah & $502.792 .000,00$ \\
\hline \multirow[t]{3}{*}{9.} & \multirow[t]{3}{*}{$\begin{array}{l}\text { Kepala UPT Pusat } \\
\text { Kesehatan Hewan }\end{array}$} & $\begin{array}{l}\text { Program Pencegahan dan } \\
\text { Penanggulangan Penyakit Ternak }\end{array}$ & 257.149.000,00 \\
\hline & & $\begin{array}{l}\text { Program Peningkatan Produksi } \\
\text { Hasil Peternakan }\end{array}$ & $9.240 .000,00$ \\
\hline & & Jumlah & 284.389.000,00 \\
\hline \multirow[t]{4}{*}{10.} & \multirow[t]{4}{*}{$\begin{array}{l}\text { Kepala UPT RPH dan } \\
\text { Labkesmavet }\end{array}$} & $\begin{array}{l}\text { Program Pencegahan dan } \\
\text { Penanggulangan Penyakit Ternak }\end{array}$ & $38.508 .000,00$ \\
\hline & & $\begin{array}{l}\text { Program Pelayanan Kesehatan } \\
\text { Masyarakat Veteriner }\end{array}$ & $380.761 .000,00$ \\
\hline & & Jumlah & 419.269.000,00 \\
\hline & & Total Anggaran & 5.148.271.000,00 \\
\hline
\end{tabular}

Sumber: Lampiran Keputusan Kepala Dinas Pertanian dan Pangan Kota Magelang Tahun 2019

Tabel di atas adalah hasil keputusan Kepala Dinas Pertanian dan Pangan Kota Magelang selaku pengguna anggaran tentang Penunjukan Pejabat Pelaksana Teknis Kegiatan (PPTK) Belanja Langsung pada Dinas Pertanian dan Pangan Kota Magelang Tahun 2020. Kepala Dinas Pertanian dan Pangan Kota Magelang Selaku Pengguna Anggaran menimbang bahwa dalam rangka melaksanakan tertib administrasi penata usahaan anggaran dalam rangka pelaksanaan APBD Tahun Anggaran 2020 pada Dinas Pertanian dan Pangan Kota Magelang perlu menunjuk dan menetapkan Pejabat Pelaksana Teknis Kegiatan Belanja
Langsung. Kemudian personil yang ditunjuk dipandang mampu dan mempunyai kompetensi serta kemampuan profesi untuk melaksanakan tugas yang diberikan, dan untuk menjalankan tujuan tersebut perlu ditetapkan dengan Surat Kepala Dinas Pertanian dan Pangan Kota Magelang.

Kepala Dinas Pertanian dan Pangan Kota Magelang menunjuk para Pejabat Pelaksana Teknis Kegiatan (PPTK) Belanja Langsung pada Organisasi Perangkat Daerah Dinas Pertanian dan Pangan Kota Magelang Tahun Anggaran 2020 sebagaimana tersebut pada lampiran keputusan ini. Pejabat Pelaksana Teknis 
Kegiatan (PPTK) Belanja Langsung pada Organisasi Perangkat Daerah Dinas Pertanian dan Pangan Kota Magelang Tahun Anggaran 2020 mempunyai tugas, yaitu mengatur pelaksanaan kegiatan Belanja Langsung, melaporkan bagaimana perkembangan pelaksanaan kegiatan Belanja Langsung, dan menyediakan dokumen anggaran atas beban pengeluaran pelaksanaan kegiatan Belanja Langsung.

\section{Penerapan Anggaran terhadap Kinerja Operasional}

Anggaran belanja pada kinerja operasional di Dinas Pertanian dan Pangan Kota Magelang sebelumnya melakukan perencanaan dalam menyusun anggaran belanja agar dapat memaksimalkan proses kegiatan pelaksanaan program kerja yang telah direncanakan. Perencanaan adalah awalan dalam mempersiapkan suatu program dan kegiatan yang bersifat jangka pendek, jangka menengah ataupun jangka panjang. Program adalah salah satu dari bagian-bagian utama yang harus ditetapkan terlebih dahulu, yang terdiri dari berbagai kegiatan-kegiatan penting yang dilaksanakan oleh bidang-bidang tertentu. Kegiatan yang baik dapat membantu program yang telah direncanakan tercapai.

Setiap pemerintahan mempunyai rencana kerja yang wajib dilaksanakan selama ia menjabat. Program adalah gabungan berbagai kegiatan sebenarnya, terorganisasi dan terstruktur yang dilakukan oleh satu atau berbagai instansi pemerintahan ataupun dalam bentuk keterlibatan dengan masyarakat untuk mencapai sasaran dan tujuan yang telah direncanakan sebelumnya (Raharjo Adisasmita, 2011).

Pimpinan instansi tentu harus menyikapi dengan bijak saat menyusun rencana anggaran sehingga dapat mendahulukan yang utama. Program yang telah dibuat Dinas Pertanian dan Pangan Kota Magelang harus betul-betul yang memberikan manfaat bagi masyarakat dan lingkungan. Peserta yang mengikuti program kegiatan pemerintah dari Dinas Pertanian dan Pangan Kota Magelang bukan seluruhnya dari masyarakat luar, namun ada juga dari kelompok binaan dari Dinas Pertanian dan Pangan Kota Magelang.

Menurut LAN-RI (1999) masukan (input), merupakan keluaran atau hasil secara langsung dari proses (output) dalam organisasi dengan segala sesuatu yang diperlukan supaya dalam pelaksanaan kegiatan dapat berjalan sesuai rencana. Dinas Pertanian dan Pangan Kota Magelang mendukung pelaksanaan kerja yang telah direncanakan sebelumnya dengan memberikan dana anggaran yang dibutuhkan untuk menjalankan program kegiatan, sumber daya manusia, peralatan yang digunakan serta sesuatu yang diperlukan agar dapat berjalan lancar dalam 
menjalankan program dan kegiatan. Menurut Sancoko (2008), keluaran (output) merupakan ukuran kinerja yang sesuai dengan produk (barang atau jasa) yang dihasilkan dari program atau kegiatan berdasarkan dengan masukan yang dipakai. Output yang dihasilkan oleh Dinas Pertanian dan Pangan Kota Magelang yaitu mengenai pelatihan-pelatihan yang telah disediakan dan memberikan manfaat yang besar untuk masyarakat banyak. Ada berbagai macam jumlah pelatihan-pelatihan yang disediakan oleh Dinas Pertanian dan Pangan Kota Magelang sehingga masyarakat dari kelompok lain juga bisa mendapatkan manfaatnya, kegiatan ini didukung oleh jumlah peserta yang mengikuti pelatihan tersebut. Hasil (outcome), merupakan ukuran kinerja yang sesuai dengan tingkat keberhasilan yang telah dicapai dan didasarkan pada keluaran program atau kegiatan yang telah dijalankan (Sancoko, 2008). Outcome (hasil) dari program atau kegiatan yang telah disediakan oleh Dinas Pertanian dan Pangan Kota Magelang mengharapkan supaya masyarakat mendapatkan kepuasaan saat mengikuti kegiatan pelatihan dan dapat mengelola dengan baik untuk diterapkan sebagaimana mestinya serta memberikan manfaat yang besar bagi masyarakat sehingga kesejahteraan dari pihak yang diberikan pelatihan dapat meningkat serta mendapat tambahan pengetahuan baru agar bisa diterapkan dan dimanfaatkan dengan baik dan bijak untuk meningkatkan kegiatan ekonomi masyarakat.

\section{Hambatan dan Upaya yang dilakukan dalam Penerapan Anggaran}

Berdasarkan hasil penelitian yang telah dilakukan dapat dilihat bahwa masih terdapat kekurangan saat melaksanakan penerapan anggaran terhadap kinerja operasional di Dinas Pertanian dan Pangan Kota Magelang. Dalam penerapannya masih ditemukan hambatan-hambatan yang terjadi. Secara teori tidak ada hambatan yang ditemui karena sudah terciptanya kontrol, aturan dan prosedur yang telah tersedia. Namun ada juga hambatan yang ditemui secara non teknis yang disebabkan karena adanya miss planning, yaitu hal yang tidak terduga dan berada diluar perencanaan yang telah dianggarkan.

Hambatan yang terjadi di Dinas Pertanian dan Pangan Kota Magelang saat melaksanaan kegiatan berlangsung yaitu ketika dalam pelatihan-pelatihan yang diberikan kepada masyarakat. Ketika telah merencanakan anggaran untuk pelatihan masyarakat dan sudah menentukan jumlah orang yang mengikuti pelatihan tersebut, terkadang ada hal yang tidak terduga dan berada diluar perencanaan yaitu terlalu banyak orang yang ingin mengikuti pelatihan yang telah diselenggarakan oleh Dinas Pertanian dan Pangan Kota 
Magelang. Hambatan lain yang dimiliki adalah masih rendahnya kemampuan yang dimiliki SDM terkait penerapan anggaran terhadap kinerja operasional yang dimiliki Dinas Pertanian dan Pangan Kota Magelang. Tingkat pelaksanaan terjadi sebesar $90 \%$ dan tingkat hambatannya hanya sebesar 10\% karena itu wajar apabila terjadi dalam pelaksanaan kegiatan tersebut.

Tindakan yang dilakukan Dinas Pertanian dan Pangan Kota Magelang untuk mengatasi hambatan tersebut, dengan cara melakukan negosiasi terhadap masyarakat. Dinas Pertanian dan Pangan Kota Magelang tidak mungkin mengabaikan masyarakat karena instansi pemerintahan ini terbentuk untuk kesejahteraan masyarakat, namun Dinas sendiri juga mempunyai keterbatasan anggaran, sehingga bagaimana hal tersebut dapat tersampaikan kepada masyarakat. Masyarakat ada yang bijak dan bisa menerima keputusan tersebut, tapi ada juga masyarakat yang kurang bisa menerima keputusan tersebut. Negosiasi tersebut dengan cara masyarakat tetap bisa mengikuti pelatihan yang telah diselenggarakan Dinas Pertanian dan Pangan Kota Magelang tapi tidak bisa mengikuti pelatihan secara keseluruhan atau masyarakat tetap bisa mengikuti pelatihan secara keseluruhan namun pada tahun berikutnya. Keterbatasan berkaitan dengan SDM di Dinas Pertanian dan Pangan Kota Magelang yaitu dengan meningkatkan kualitas SDM sehingga seluruh pengurus harus dituntut untuk bisa melakukan apapun, agar bisa saling membantu dan melengkapi dalam kegiatan pelaksanaan tersebut. Adanya kendala dilapangan dengan anggaran yang sudah ada sebisa mungkin Dinas Pertanian dan Pangan Kota Magelang akan melaksanakannya dengan $100 \%$.

Menurut penjelasan diatas dapat disimpulkan bahwa dalam mekanisme penerapan anggaran belanja di Dinas Pertanian dan Pangan Kota Magelang, setelah disahkan dan disetujui menjadi APBD maka RKA diubah menjadi DPA. Anggaran pada kinerja operasional di Dinas Pertanian dan Pangan Kota Magelang membuat program kegiatan yang dapat memberikan manfaat bagi masyarakat dan lingkungan. Selain itu, terdapat beberapa hambatan dalam pelaksanaan program kegiatan antara lain (1) hal yang tidak terduga dan berada diluar dari perencanaan serta; (2) adanya keterbatasan SDM di Dinas Pertanian dan Pangan Kota Magelang.

\section{KESIMPULAN}

Berdasarkan pembahasan dan hasil penelitian yang telah dilakukan terkait Penerapan Belanja Anggaran Terhadap Kinerja Operasional di Dinas Pertanian dan Pangan Kota Magelang, maka dapat ditarik kesimpulan sebagai berikut: 
1. Pelaksanakan anggaran belanja pada kinerja operasional Dinas Pertanian dan Pangan Kota Magelang akan melakukan perencanaan untuk menyusun anggaran sehingga dapat memaksimalkan proses kegiatan pelaksanaan program kerja yang mempunyai perencanaan jangka pendek, jangka menengah dan jangka panjang.

2. Pejabat yang berwenang dalam hal pelaksanaan anggaran di Dinas Pertanian dan Pangan Kota Magelang adalah PA (Pengguna Anggaran), yaitu Kepala Dinas Pertanian dan Pangan Kota Magelang. Dalam proses pelaksanaan anggaran, PA akan medelegasikan kepada kepala bidang yang diturunkan ke tingkat pelaksanaan kegiatan disebut PPTK (Pejabat Pelaksana Teknis Kegiatan) dan juga harus bertanggungjawab dalam setiap kegiatan.

3. Anggaran belanja pada kinerja operasional di Dinas Pertanian dan Pangan Kota Magelang telah membuat perencanaan berupa program yang terdiri dari berbagai macam kegiatan-kegiatan yang dijalankan oleh bidang-bidang tertentu.

4. Pengukuran kinerja berupa input yang digunakan untuk mendukung program kegiatan yang telah dibuat oleh Dinas
Pertanian dan Pangan Kota Magelang yaitu disediakannya dana anggaran yang dibutuhkan, sumber daya manusia, peralatan yang digunakan. Dan output-nya yaitu kegiatan pelatihan-pelatihan yang telah disediakan dan memberikan manfaat yang besar bagi masyarakat banyak. Serta outcome dari program atau kegiatan mengharapkan supaya masyarakat mendapatkan kepuasaan saat mengikuti kegiatan pelatihan dan mendapat tambahan pengetahuan baru agar bisa diterapkan dan dimanfaatkan dengan baik dan bijak untuk meningkatkan kegiatan ekonomi masyarakat.

5. Hambatan yang ditemui dalam pelaksanaan kegiatan adalah hal yang tidak terduga dan berada diluar dari perencanaan serta adanya keterbatasan SDM di Dinas Pertanian dan Pangan Kota Magelang. Langkah yang diambil dalam mengatasi hambatan tersebut adalah pihak Dinas Pertanian dan Pangan Kota Magelang melakukan negosiasi terhadap masyarakat karena adanya keterbatasan anggaran.

\section{DAFTAR PUSTAKA}

Adisasmita, R. (2011). Manajemen Pemerintahan Daerah. Yogyakarta: Geraha Ilmu. 
Avionita, V. (2013). Pengaruh Anggaran Berbasis Kinerja Terhadap Kinerja Program Peningkatan Disiplin Aparatur Instansi Pemerintah Daerah.

Cipta, H. (2011). Analisis Penerapan Penganggaran Berbasis Kinerja (Performance Based Budgeting) Pada Pemerintah Daerah (Studi Eksploratif Pada Pemerintah Kabupaten Tanah Datar).

Daft, R. (2010). Era Baru Manajemen (Edisi 9, Buku 2). Jakarta: Salemba Empat. Djam'an Satori, \& Komariah, A. (2011).

Metode Penelitian Kualitatif. Alfabeta, Bandung.

Espinoza. (2014). Pengaruh Penerapan Anggaran Berbasis Kinerja Terhadap Kinerja Keuangan.

Handoko, H. (2010). Manajemen Personalia \& Sumberdaya Manusia (Edisi Kedua). Yogyakarta: BPFE UGM.

Haryanto, Sahmuddin, \& Arifuddin. (2007). Akuntansi Sektor Publik. Semarang: Badan Penerbit Universitas Diponegoro.

Herawati. (2018). Analisis Perencanaan dan Pengawasan Biaya Operasional Pada PT. Socfin Indonesia Perkebunan Tanah Gambus Kec. Lima Puluh Kab. Batubara.

Izzaty, K. N. (2011). Pengaruh Gaya Kepemimpinan dan Kualitas Sumber
Daya Manusia Terhadap Penerapan Anggaran Berbasis Kinerja Badan Layanan Umum.

LAN RI. (1999). Prinsip-Prinsip Penyelenggaraan Negara. Jakarta.

Laporan Kinerja Instansi Pemerintah (LKJiP) Dinas Pertanian dan Pangan Kota Magelan Tahun 2018. (2018). Magelang.

Mardiasmo. (2002). Akuntansi Sektor Publik. Yogyakarta: Andi.

Mulihartanti, M. T. (2013). Analisis Penerapan Penganggaran Berbasis Kinerja Pada Pemerintah Kota Administrasi Jakarta Utara (Studi Kasus Untuk Tahun Anggaran 2011).

Nafarin, M. (2013). Penganggaran Perusahaan. Edisi ketiga, Cetakan kedua, Buku 1. Jakarta: Salemba Empat.

Nanda, R., \& Darwanis. (2016). Analisis Implementasi Anggaran Berbasis Kinerja Pada Pemerintah Daerah (Studi Deskriptif Pada Dinas DPKKD Kabupaten Aceh Selatan). Jurnal Ilmiah Mahasiswa Ekonomi Akuntansi (JIMEKA) Vol. 1, No. 1, 327-340.

Nawawi, H., \& Martini, M. (1996). Penilitian Terapan. Yogyakarta: Gadjah Mada University Press. Noratika, Novriyani, Sulazmi, Mardika, R. S., Noviasari, G., Rostiyana, A., \& 
Nurlaela, E. (2016/2017). Makalah

Penganggaran Sektor Publik.

Retrieved from

elanurlaela433.blogspot.com:

https://elanurlaela433.blogspot.com/

2016/04/makalah-penganggaran-

sektor-publik.html

Peraturan Pemerintah Nomor 8 Tahun 2006

tentang Pelaporan Keuangan dan

Kinerja instansi Pemerintah.

Rustiyani, T. (2007). Pengaruh Partisipasi

Dalam Penyusunan Anggaran

Terhadap Kinerja Manajerial :

Strategi dan Struktur Organisasi sebagai Variabel Moderating

(Survey pada Perusahaan

Manufaktur

Se-Karesidenan

Surakarta).

Sancoko, B. (2008). Kajian terhadap Penganggaran Berbasis Kinerja di Indonesia. Badan Pendidikan dan Pelatihan Keuangan, Departemen Keuangan RI.

Sri Rahayu. (2007). Studi Fenomenologis terhadap Proses Penyusunan Anggaran Daerah (Bukti Empiris dari Satu Satuan Kerja Perangkat Daerah di Propinsi Jambi). Simposium Nasional Akuntansi X.

Supriyono, R. A. (1999). Akuntansi Manajemen 1 (Edisi 1, Cetakan Kelima). Yogyakarta: BPFE.

Widiyanti, S. A. (2016). Analisis Pengaruh Operational Performance dan
Service Quality Terhadap Customer

Satisfaction dan Dampaknya Terhadap Customer Loyalty (Studi Kasus : PT Timas Suplindo). 
JAFTA - Vol 2 Nomor 2, Februari (2021) 